\title{
Human Rabies - Wyoming and Utah, 2015
}

\begin{abstract}
Alexia Harrist, MD, PhD ${ }^{1,2}$; Ashley Styczynski, MD ${ }^{1,3}$; DonRaphael Wynn, MD 4 ; Safdar Ansari, MD ${ }^{4}$; Justin Hopkin, MD Harry Rosado-Santos, MD6; JoDee Baker, MPH ${ }^{7}$; Allyn Nakashima, $\mathrm{MD}^{7}$; Annette Atkinson MS ${ }^{7}$; Melanie Spencer, MPH ${ }^{8}$; Debbie Dean, $\mathrm{MSN}^{8}$; Leslie Teachout, $\mathrm{MT}^{5}$; Jeanmarie Mayer, $\mathrm{MD}^{9}$; Rene E. Condori, $\mathrm{MS}^{3}$; Lillian Orciari, $\mathrm{MS}^{3}$; Ashutosh Wadhwa, $\mathrm{PhD}^{3}$; James Ellison, $\mathrm{PhD}^{3}$; Michael Niezgoda ${ }^{3}$; Brett Petersen, MD $^{3}$; Ryan Wallace, DVM ${ }^{3}$; Karl Musgrave, DVM²
\end{abstract}

In September 2015, a Wyoming woman was admitted to a local hospital with a 5-day history of progressive weakness, ataxia, dysarthria, and dysphagia. Because of respiratory failure, she was transferred to a referral hospital in Utah, where she developed progressive encephalitis. On day 8 of hospitalization, the patient's family told clinicians they recalled that, 1 month before admission, the woman had found a bat on her neck upon waking, but had not sought medical care. The patient's husband subsequently had contacted county invasive species authorities about the incident, but he was not advised to seek health care for evaluation of his wife's risk for rabies. On October 2, CDC confirmed the patient was infected with a rabies virus variant that was enzootic to the silver-haired bat (Lasionycteris noctivagans). The patient died on October 3. Public understanding of rabies risk from bat contact needs to be improved; cooperation among public health and other agencies can aid in referring persons with possible bat exposure for assessment of rabies risk.

\section{Case Report}

On September 22, 2015, a Wyoming woman aged 77 years with a history of mild dementia was evaluated at a local emergency department with a 5-day history of progressive weakness and ataxia after a fall. On examination, she had slurred speech, could not swallow water, and could not stand without assistance. Initial blood tests did not indicate any specific abnormalities; lumbar puncture was not performed. Urinalysis suggested urinary tract infection, and intravenous ceftriaxone was started; urine culture subsequently grew pansensitive Escherichia coli. Magnetic resonance imaging (MRI) of the brain and spine revealed no acute pathology.

During the first 2 days of hospitalization, the patient's weakness, dysarthria, and dysphagia progressed. She became increasingly confused and dyspneic and positive pressure ventilation was started. Lumbar puncture was performed on September 24; cerebrospinal fluid (CSF) had elevated protein of $64 \mathrm{mg} / \mathrm{dL}$ (normal $=15-45 \mathrm{mg} / \mathrm{dL}$ ) and a white blood cell count of 7 cells $/ \mu \mathrm{L}$ (normal $=0-5$ cells $/ \mu \mathrm{L}$ ) with $72 \%$ polymorphonuclear leukocytes and 28\% lymphocytes. Electromyography and nerve conduction studies suggested a demyelinating process. A presumptive diagnosis of Guillain-Barré syndrome was made, and intravenous immunoglobulin (Ig) therapy was initiated.

On September 26, the patient required endotracheal intubation for worsening respiratory failure, and on September 27,

\section{INSIDE}

534 Cigarette Smoking Among Urban American Indian Adults - Hennepin and Ramsey Counties, Minnesota, 2011

538 Public Confidence in the Health Care System 1 Year After the Start of the Ebola Virus Disease Outbreak - Sierra Leone, July 2015

543 Interim Guidance for Interpretation of Zika Virus Antibody Test Results

547 Notes from the Field: Investigation of Hepatitis C Virus Transmission Associated with Injection Therapy for Chronic Pain — California, 2015

550 Notes from the Field: Increase in Neisseria meningitidis-Associated Urethritis Among Men at Two Sentinel Clinics - Columbus, Ohio, and Oakland County, Michigan, 2015

553 QuickStats

Continuing Education examination available at http://www.cdc.gov/mmwr/cme/conted_info.html\#weekly.

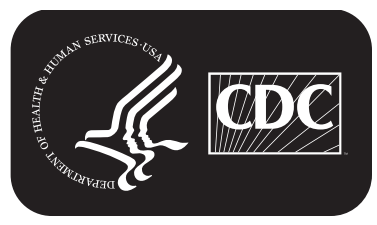

U.S. Department of Health and Human Services Centers for Disease Control and Prevention 
she was transferred to a referral hospital in Utah. Examination on arrival revealed near complete quadriplegia and spontaneous myoclonus. During the next 5 days the woman became comatose. Repeat brain and spine MRI revealed new enhancement of the dura, trigeminal nerve, and cauda equina, indicative of a central infiltrative process. Tests of blood and CSF for infectious, oncologic, and autoimmune etiologies were unrevealing.

On September 30 (13 days after initial symptom onset and day 8 of hospitalization), family members reported that on August 22, 2015, the patient awoke at night in her home with a bat on her neck, which she swatted away with her hand (Figure). She immediately washed her hand with soap and water; her husband examined her for bite wounds and found none. She did not seek medical attention. Her husband captured the bat with gloved hands and released it outside.

On October 1, the Utah Department of Health coordinated the collection and shipment of specimens to CDC for rabies virus diagnostic evaluation. Rabies virus RNA was detected in nuchal skin biopsy and saliva by reverse transcription-polymerase chain reaction. Rabies virus antigens were found in nuchal skin biopsy by direct fluorescent antibody testing, and rabies IgM and IgG were detected in CSF and serum by indirect fluorescent-antibody assay, and confirmed by the rapid fluorescent focus inhibition test. The rabies virus variant was identified as one enzootic to the silver-haired bat (Lasionycteris noctivagans). The woman died on October 3, 2015. She was the first Wyoming resident with confirmed rabies virus infection since the state began documenting reportable infectious diseases in 1911.

\section{Public Health Investigation}

After rabies infection was confirmed on October 2, Salt Lake County Health Department and Wyoming Department of Health (WDH) personnel interviewed 15 family members and community contacts to assess rabies exposure risk from contact with the patient and from bat encounters in the patient's home. The patient's husband and one other family member required postexposure prophylaxis (PEP) because of potential contact with the woman's saliva through kissing or sharing of food and drinks during the woman's infectious period. Because rabies virus can be shed in saliva and tears 2 weeks before symptom onset, the infectious period began on September 4, 2015, 2 weeks before she fell at home on September 18 (Figure). The patient's husband also required PEP because of his potential bat exposure on August 22. Two other contacts chose to receive PEP although they did not report exposures that would constitute increased risk for acquiring rabies (Table) (1).

WDH worked with the Wyoming hospital to assess rabies exposure risk among the patient's health care providers. The employee health department at the Utah hospital instructed personnel with potential exposure of nonintact skin or mucous membranes to the patient's saliva, tears, respiratory tract secretions, CSF, or nuchal biopsy specimens to discuss PEP with the employee health medical director. Between the Wyoming and Utah hospitals, 100 health care providers had cared for the patient; 22 (22\%) received PEP (Table).

The MMWR series of publications is published by the Center for Surveillance, Epidemiology, and Laboratory Services, Centers for Disease Control and Prevention (CDC), U.S. Department of Health and Human Services, Atlanta, GA 30329-4027.

Suggested citation: [Author names; first three, then et al., if more than six.] [Report title]. MMWR Morb Mortal Wkly Rep 2016;65:[inclusive page numbers].

\author{
Centers for Disease Control and Prevention \\ Thomas R. Frieden, MD, MPH, Director \\ Harold W. Jaffe, MD, MA, Associate Director for Science \\ Joanne Cono, MD, ScM, Director, Office of Science Quality \\ Chesley L. Richards, MD, MPH, Deputy Director for Public Health Scientific Services \\ Michael F. Iademarco, MD, MPH, Director, Center for Surveillance, Epidemiology, and Laboratory Services
}

MMWR Editorial and Production Staff (Weekly)
Martha F. Boyd, Lead Visual Information Specialist

Maureen A. Leahy, Julia C. Martinroe,

Stephen R. Spriggs, Moua Yang, Tong Yang, Visual Information Specialists

Quang M. Doan, MBA, Phyllis H. King, Terraye M. Starr, Information Technology Specialists
MMWR Editorial Board

Timothy F. Jones, MD, Chairman

Matthew L. Boulton, MD, MPH Virginia A. Caine, MD

Katherine Lyon Daniel, $\mathrm{PhD}$

Jonathan E. Fielding, MD, MPH, MBA

David W. Fleming, MD

\author{
William E. Halperin, MD, DrPH, MPH \\ King K. Holmes, MD, PhD \\ Robin Ikeda, MD, MPH \\ Rima F. Khabbaz, MD \\ Phyllis Meadows, PhD, MSN, RN \\ Jewel Mullen, MD, MPH, MPA
}

\author{
Jeff Niederdeppe, $\mathrm{PhD}$ \\ Patricia Quinlisk, MD, MPH \\ Patrick L. Remington, MD, MPH \\ Carlos Roig, MS, MA \\ William L. Roper, MD, MPH \\ William Schaffner, MD
}




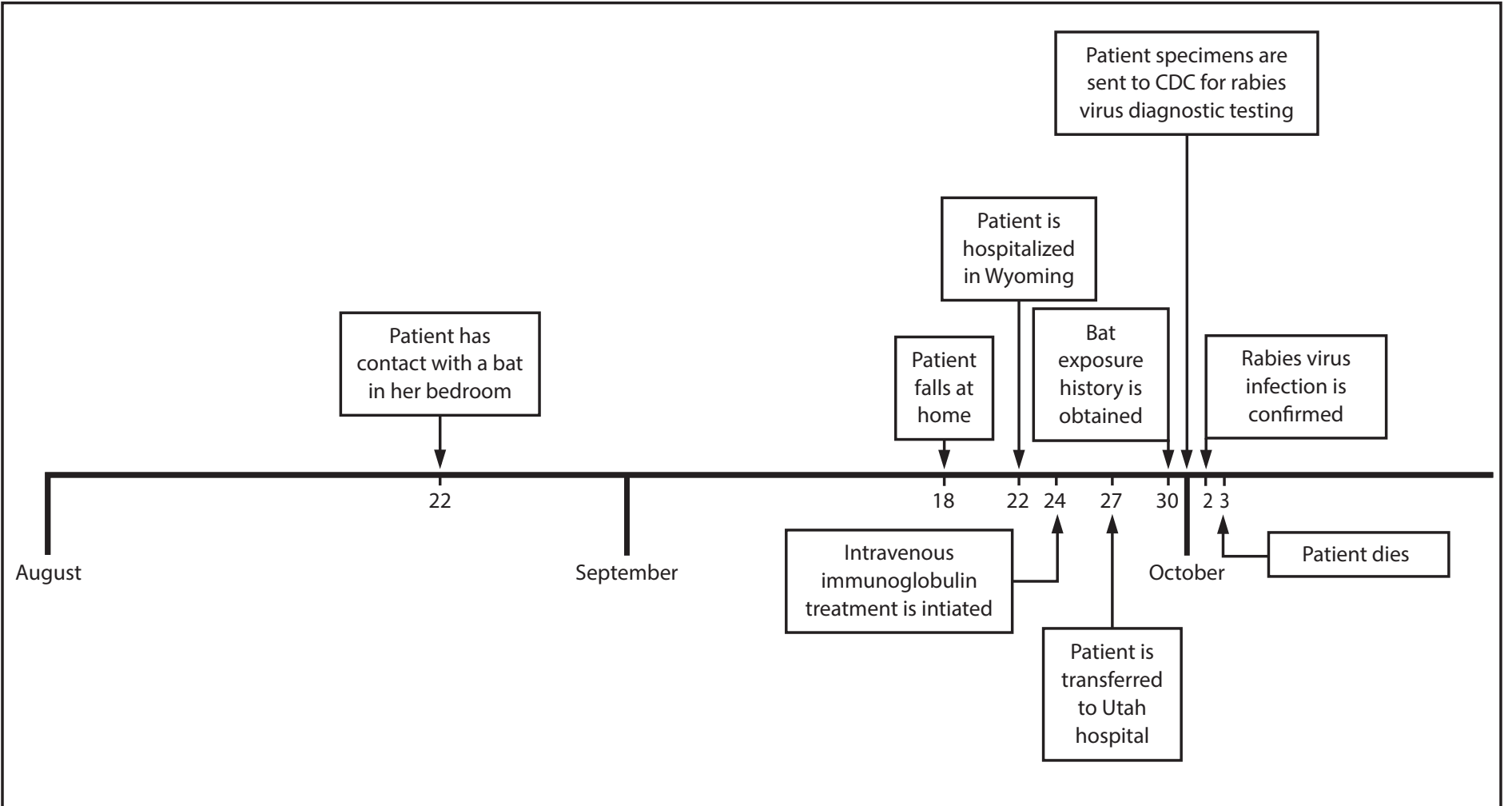

TABLE. Reported reasons for receipt of rabies postexposure prophylaxis (PEP) among 100 hospital care providers and 15 family members and community contacts of a woman patient with fatal rabies virus infection - Wyoming and Utah, 2015

\begin{tabular}{lcc}
\hline Reason for receiving PEP & $\begin{array}{c}\text { Hospital care } \\
\text { providers } \\
\text { No. (\%) }\end{array}$ & $\begin{array}{c}\text { Family members and } \\
\text { community contacts } \\
\text { No. (\%) }\end{array}$ \\
\hline $\begin{array}{l}\text { Possible exposure to patient saliva, sputum, or tears } \\
\text { Nonintact skin }\end{array}$ & $3(3)$ & $0(-)$ \\
$\begin{array}{l}\text { Mucous membranes } \\
\text { Both nonintact skin and mucous }\end{array}$ & $4(4)$ & $2(13)^{*}$ \\
membranes & $3(3)$ & $0(-)$ \\
$\begin{array}{l}\text { Intact skin } \\
\text { Bat contact at the patient's home }\end{array}$ & $2(2)$ & $0(-)$ \\
No reported exposure but chose & N/A & $1(7)^{*}$ \\
to receive PEP & $10(10)$ & $2(13)$ \\
Total & $22(22)$ & $4(27)$ \\
\hline
\end{tabular}

Abbreviation: N/A = not applicable.

* The patient's husband had both possible mucous membrane exposure to patient saliva, sputum, or tears, and possible bat contact at the patient's home. † Not considered an exposure requiring PEP by the Advisory Committee on Immunization Practices. CDC. Human rabies prevention-United States, 2008: recommendations of the Advisory Committee on Immunization Practices. MMWR Recomm Rep 2008;57(No. RR-3).

During further interviews with the patient's family, local public health workers and WDH learned that the patient's husband had consulted a county weed and invasive species authority about the bat incident during the week after it occurred, but he was neither informed about the risk for rabies exposure nor referred to medical or public health officials. The family also reported that during the multiple years they had owned their home, they had often seen bats outside and under the eaves of the home, and that the patient and her husband had occasionally encountered bats inside the home. They reported having contacted multiple authorities from local wildlife, invasive species, and health agencies about bat removal over the years, but said they had never received information concerning rabies.

On October 2, 2015, WDH issued a press release with recommendations for preventing rabies, including when to seek medical attention for possible rabies exposure. WDH staff members also contacted county authorities to provide information regarding rabies risk and ensure that correct referrals to public health agencies would be made in the future.

\section{Discussion}

Rabies is a nearly universally fatal zoonotic disease caused by infection with viruses of the genus Lyssavirus and characterized by acute progressive encephalitis (2). Rabies virus is usually transmitted by an animal bite, and is preventable if exposed persons receive appropriate PEP, which includes thorough wound cleansing, human rabies immunoglobulin, and 4 doses of inactivated rabies vaccine on days $0,3,7$, and 14 (3).

Human rabies presents a diagnostic challenge because of its rare occurrence in the United States and varied clinical 
presentations; symptoms can be difficult to distinguish from Guillain-Barré syndrome (2). Although the patient had prominent dysphagia, a symptom that is rare in other etiologies of encephalitis (4), diagnosis was complicated by her preexisting dementia and acute urinary tract infection, both of which might have explained some of her symptoms. In this case, the history of bat exposure was critical in leading clinicians to consider a diagnosis of rabies; however, because a history of animal bite cannot be documented in the majority of rabies cases in the United States (5), clinicians should consider a diagnosis of rabies infection in any patient with acute unexplained encephalitis ( 6 ).

The prolonged hospitalization of the patient described in this report raised concerns about possible exposures among health care providers. PEP is only indicated for health care providers who have mucous membrane or open skin contact with saliva, tears, or nervous tissue (1). Consistent adherence to standard precautions among providers could have reduced the need for PEP $(1,6,7)$. The Hospital Infection Control Practices Advisory Committee recommends standard precautions for all hospitalized patients, including situations in which a transmissible infectious disease is not initially suspected (7).

The patient described in this report likely acquired rabies through the reported bat exposure in the home. During recent decades, most domestically acquired human rabies cases have been associated with bat exposures, either by history of bat contact or infection with bat-associated rabies virus variants $(6,8)$; however, in the majority of these cases, no bite was reported $(5,8)$. Because bat bites can cause limited injury and therefore can be difficult to detect (9), the Advisory Committee on Immunization Practices recommends that any person with direct bat contact or who might be unaware of bat contact (e.g., awakening with a bat in the room) undergo evaluation for rabies virus exposure (1).

In this case, the patient and her husband, her primary caregiver, were unaware of the risk for rabies in the absence of a visible bite wound, did not seek medical evaluation, and did not receive PEP. The reported multiple past telephone calls by the patient's family to local authorities regarding bats represent missed opportunities to provide rabies education. Similar missed opportunities were reported in a previous human rabies case in the United States (10). These cases indicate the need to not only increase public awareness of rabies transmission risk from bat exposure, but also the need to educate public agencies outside of the public health domain to ensure that they can provide accurate information and proper referrals.

\section{Summary}

What is already known about this topic?

Rabies is a nearly universally fatal zoonotic disease, but is preventable if exposed persons receive postexposure prophylaxis (PEP). During recent decades, most domestically acquired human rabies cases in the United States have been associated with bat exposures; however, in the majority of these cases, no bite was reported. What is added by this report?

In 2015, a Wyoming woman aged 77 years died from infection with a rabies virus variant enzootic to the silver-haired bat. The patient had contact with a bat while sleeping, but she and her husband, her primary caregiver, were unaware of the risk for rabies in the absence of a visible bite wound; they did not seek medical evaluation or receive PEP after the incident. The patient's family had reportedly contacted several local agencies about bats near their home over multiple years, but had not been informed about the risk for rabies.

What are the implications for public health practice?

Public understanding of rabies exposure risk from bat contact needs to be improved. Cooperation among public health and other agencies can aid in referring persons with potential bat exposure for rabies risk assessment.

\section{Acknowledgments}

Cindy Herrera, Julie Twist, Fremont County Health Department, Wyoming.

\footnotetext{
${ }^{1}$ Epidemic Intelligence Service, CDC; ${ }^{2}$ Wyoming Department of Health; ${ }^{3}$ Poxvirus and Rabies Branch, National Center for Emerging and Zoonotic Infectious Diseases, CDC; ${ }^{4}$ Department of Neurology, University of Utah, Salt Lake City; ${ }^{5}$ SageWest Health Care, Lander, Wyoming; ${ }^{6}$ Department of Internal Medicine, Division of Infectious Diseases, University of Utah, Salt Lake City; ${ }^{7}$ Utah Department of Health; ${ }^{8}$ Salt Lake County Health Department, Utah;

${ }^{9}$ Department of Internal Medicine, University of Utah, Salt Lake City.
}

Corresponding author: Alexia Harrist, alexia.harrist@wyo.gov, 307-777-5532.

\section{References}

1. Manning SE, Rupprecht CE, Fishbein D, et al. Human rabies prevention-United States, 2008: recommendations of the Advisory Committee on Immunization Practices. MMWR Recomm Rep 2008;57(No. RR-3).

2. Hemachudha T, Laothamatas J, Rupprecht CE. Human rabies: a disease of complex neuropathogenetic mechanisms and diagnostic challenges. Lancet Neurol 2002;1:101-9. http://dx.doi.org/10.1016/S1474-4422(02)00041-8

3. Rupprecht CE, Briggs D, Brown CM, et al. Use of a reduced (4-dose) vaccine schedule for postexposure prophylaxis to prevent human rabies: recommendations of the advisory committee on immunization practices. MMWR Recomm Rep 2010;59(No. RR-2).

4. CDC. Recovery of a patient from clinical rabies-California, 2011. MMWR Morb Mortal Wkly Rep 2012;61:61-5.

5. Messenger SL, Smith JS, Rupprecht CE. Emerging epidemiology of bat-associated cryptic cases of rabies in humans in the United States. Clin Infect Dis 2002;35:738-47. http://dx.doi.org/10.1086/342387 
6. Pratt PD, Henschel K, Turabelidze G, et al. Human rabies-Missouri, 2014. MMWR Morb Mortal Wkly Rep 2016;65:253-6. http://dx.doi. org/10.15585/mmwr.mm6510a1

7. Siegel JD, Rhinehart E, Jackson M, Chiarello L; Healthcare Infection Control Practices Advisory Committee. 2007 guideline for isolation precautions: preventing transmission of infectious agents in healthcare settings. http://www.cdc.gov/hicpac/pdf/isolation/Isolation2007.pdf
8. Feder HM Jr, Petersen BW, Robertson KL, Rupprecht CE. Rabies: still a uniformly fatal disease? Historical occurrence, epidemiological trends, and paradigm shifts. Curr Infect Dis Rep 2012;14:408-22. http://dx.doi. org/10.1007/s11908-012-0268-2

9. Feder HM Jr, Nelson R, Reiher HW. Bat bite? Lancet 1997;350:1300. http://dx.doi.org/10.1016/S0140-6736(05)62479-8

10. CDC. Human rabies-South Carolina, 2011. MMWR Morb Mortal Wkly Rep 2013;62:642-4. 